\title{
The next step in the strategy-as-practice evolution: A comparative typology matrix
}

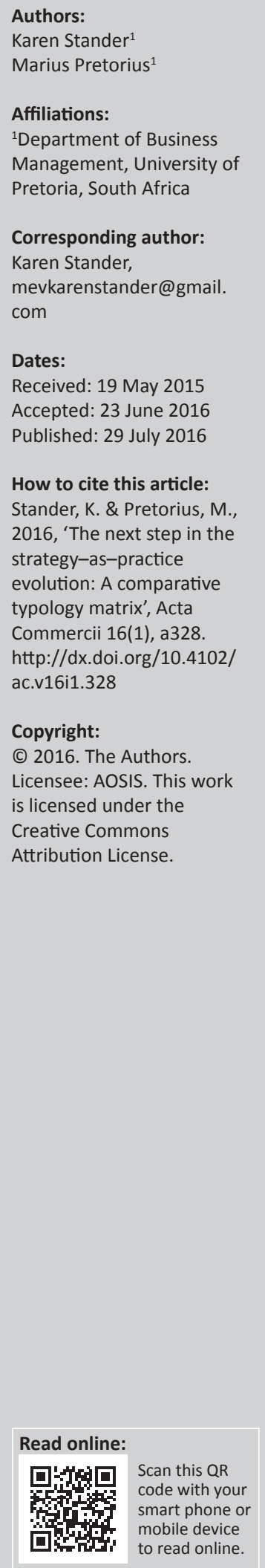

Orientation: In 2009, Strategy-as-Practice (S-as-P) research, as a subfield of strategy research, was grouped into nine different domains, and researchers were advised to frame their research within these domains. The papers or works (herein used interchangeably) published with S-as-P as subject, were counted, categorised, and a typology matrix was constructed. Researchers use this count to indicate a need for research in a specific domain.

Research purpose: The main purpose of this study is to construct a comparative S-as-P typology matrix which accurately depicts the number of papers published in each domain between 2008 and 2015.

Motivation for the study: The S-as-P typology matrix was first published in 2009 (Jarzabkowski \& Spee 2009), and at the present moment, six years later, researchers still use the dated number of papers counted in each of the S-as-P domains to indicate a research gap.

Research design, approach and method: A content analysis of all papers, listed by researchers on the official S-as-P website, was conducted. The papers were disseminated and key variables were counted.

Main findings: The comparative typology matrix shows that relative to other domains, domain D appears overly researched, whilst no research has been carried out on domains C and $\mathrm{H}$ from 2008 to 2015.

Practical/managerial implications: The comparative S-as-P typology matrix allows researchers to accurately evaluate the need for current research within the chosen domain.

Contribution/value-add: The comparative typology matrix should prevent, as is the case currently with domain $\mathrm{D}$, that domains are over-researched, whilst others receive no research attention.

\section{Introduction}

Although traditional strategy theory might be credible in the arena of management literature, the limited economic view of the discipline, which focused on the macro level of organisational operations, has subsequently divorced it from the realities of strategising. The business environment of the 21st century has forced researchers to investigate the 'DNA' of strategising to discover how an organisation should adapt, align and change its 'DNA' to emerge successfully from the dynamic external environment. The investigation of organisational 'DNA' is a further response to a societal call for strategy research to investigate the 'realities' of organisations and has seen the development of a new approach to strategy, which connects the Theory of Strategy with the Practice of Strategy: Strategy-as-Practice (Dameron, Lê \& LeBaron 2015:S1; Haugstad 1999; Johnson, Melin \& Whittington 2003:19; Whittington 2002:C1, 2007:1577).

This contemporary pull for the adaptation of practical strategy research to enable a better understanding of the doing of strategy that emerges from the change in societal preference (Carter, Clegg \& Kronberger 2008:83), has seen strategy research mimic the natural evolution of the Great White Shark. This species, faced with a choice between survival and extinction, had to adapt to its changing environment by altering its deoxyribonucleic acid (DNA) (Ehret et al. 2012:1139; Wright State University 2005:Introduction). It is the ability of the Great White Shark to change its DNA that has made it one of the great evolutionary strategists known to man, giving it a predatory advantage above other shark species. Scientists, however, hold mixed opinions regarding the evolutionary origins of the Great White Shark, some suggesting its origin to be that of the prehistoric Megalodon Shark, whilst others suggest that the Great White Shark evolved from the Mako Shark (Ehret et al. 2012:1139). 
In an effort to understand the possible sources of sustained positive performance, superior rents and competitive advantage, a debate similar to the debate on the evolutionary origin of the Great White Shark exists in the field of strategy. The numerous, mutually exclusive theories on the origins of sustained superior performance (such as the MarketBased View, Resource-Based View, Capabilities/Dynamic Capabilities-Based View, Relational View, Transient Advantage and Strategic Fit Theory), continue to fuel the debate, on what creates and sustains positive, and or, superior performance, even today $^{1}$. Most publications, as observed on Google Scholar ${ }^{2}$, in the strategy field explicitly position themselves in one of the theories, often by stating the selected view in the publication title.

If it is agreed that an organisation's strategy is its theory on how to gain competitive advantage (Barney \& Hesterly 2015:44), it can be argued that competitive advantage is central to the debate about what strategy research should seek to explain (Haugstad 1999:Introduction). Strategy-asPractice (S-as-P) has been positioned as a moderator in this debate, and by explicitly seeking to explain the practice or doing of strategy, rather than getting caught up in the strategy theory debate, S-as-P examines the social practice known as strategising (Johnson et al. 2003:13; Whittington 2002, 2007:1578). In biological DNA, the combination of bases to form a genetic sequence is near infinite. In a similar manner, the number of possible research topics contained in the S-as-P DNA, are near infinite. In an effort to structure S-as-P research, Jarzabkowski and Spee (2009:74) grouped research topics into nine different domains, known as the S-as-P typology matrix; this was carried out around two of the three elements of strategising DNA, namely praxis and practitioner.

This article reviews the typology matrix of the nine widely adopted S-as-P research domains and presents a comparative, but updated version of the typology matrix. Subsequently, in an effort to explore the possible reasons for the practice movement in research, an analysis of a purposeful sample of academic works is presented. The reasons presented serve as enabling variables to S-as-P researchers by effectively shedding light on what has been carried out and where the gap remains. Moreover, this article concludes by recommending the next step in the S-as-P evolution.

\section{Motivation for the study}

Since the construction of the S-as-P typology matrix in 2009 by Jazarbkowski and Spee (2009:74), it has been widely used in S-as-P research. The Jazarbkowski and Spee (2009:74) $\mathrm{S}$-as-P typology matrix indicates the number of empirical and theoretical papers that explicitly identify with the S-as-P agenda. Numerous researchers have used the Jazarbkowski and Spee (2009:74) typology matrix to identify a gap for $\mathrm{S}$-as-P research, and at the time of writing this article,

1.An example of the continued debate can be found in Paladino, Welding and Whitwell,2015:338.

2.Examples of titles include: Blome, Schoenherr \& Eckstein 2014:307; Dutta 2015:1; Ferlie et al. 2015:127; Molloy \& Barney 2015:309. the paper in which the typology matrix first appeared has been cited 423 times on Google Scholar and 116 times on Web of Science (Jarzabkowski \& Spee 2009:74). Six years after the paper count was performed for the original typology matrix in 2009, researchers still use the same count to indicate a research gap ${ }^{3}$ and it is evident from the data collected for this article that specific domains have been over-researched, whilst others have been neglected.

\section{Strategising DNA}

S-as-P researchers (Jarzabkowski, Balogun \& Seidl 2007:5; Jarzabkowski \& Spee 2009:70; Jarzabkowski \& Whittington 2008:282-285; Johnson et al. 2003:16) have defined the three elements of strategising DNA (S-as-P research parameters) as praxis, practice and practitioners. Although the elements of strategising DNA are separately identifiable (Figure 1) they are intrinsically connected in such a manner that it is not plausible to study one element without drawing on some aspects of the others.

Figure 1 graphically depicts the complexity of strategising DNA. The top grey layer indicates the various practices that may be employed, whilst the bottom grey layer indicates the numerous practitioners that may be involved in strategising. In an effort to facilitate an understanding of strategising DNA, only two practices and two practitioners were used in the graphical illustration, shown in Figure 1. It is however, necessary to note that there may be an unlimited number of both practices and practitioners. The arrows in Figure 1 indicate praxis as the flow between the various practices and practitioners over time. It is interesting to note the visual similarity between strategising DNA (Figure 1) and the double helix of biological DNA (Figure 2).

\section{Praxis}

Strategy praxis comprises of the interconnections between the actions of, and utilisation of resources by practitioners,

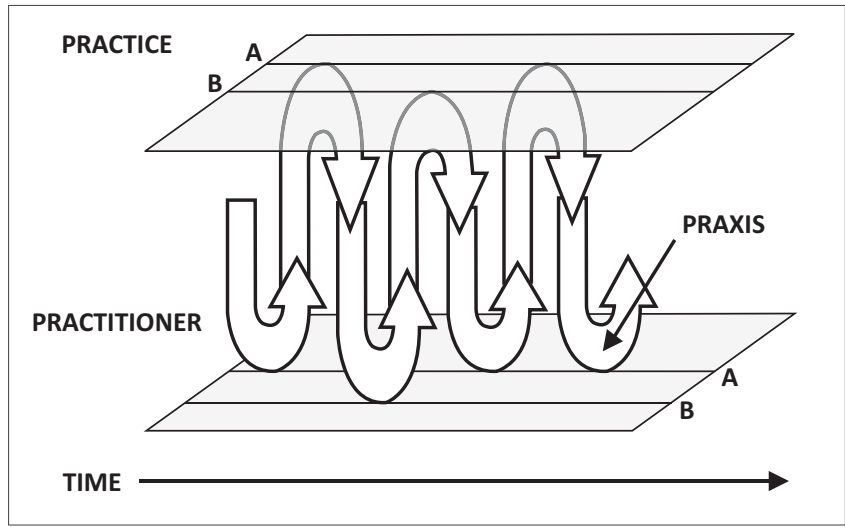

Source: Adapted from Whittington 2002:C6

FIGURE 1: Strategising DNA.

3.Examples of such papers include Hardy \& Thomas 2014:321 ('There is a need for more research that examines how locally negotiated meanings have organizationwide effects on strategy making'.); Arvidsson, Holmström \& Lyytinen 2014:47 ('Researchers have, for example, commonly investigated how these processes are shaped by actors' emotions, motivations and social and political interaction'.); Strutzenberger \& Ambos 2014:328. 


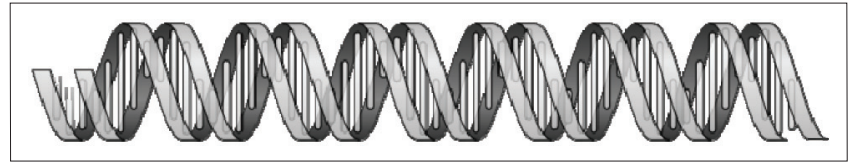

Source: All-free-download.com 2015

FIGURE 2: Double Helix of Biological DNA.

the organisation's actors and the organisation within which these individuals and groups act. This flow of activity is, however, not only in a singular direction, as these actions might run parallel, might intersect, might diverge from or depend on each other or even collide (Campbell-Hunt 2007:798; Jarzabkowski \& Spee 2009:73).

The interconnections of actions flow from a complex system which brings the independent actions of practitioners together, from which order (repeated action cycles) - known as action feedback loops - will eventually arise. These action feedback loops can be either (Campbell-Hunt 2007:797):

- Positive, enabling the evolution of internal processes, systems and capabilities that ensure the adaption of an organisation to its external environment (often resulting in the automatic correction of problems that top management might even be unaware of); or

- Negative, breaking down essential processes needed for the organisation's survival in the rapidly changing external environment.

\section{Practitioners}

These are the people (human actors) who do the work of strategy, including, but not limited to, the internal actors (in the employ of the organisation) on all levels in the organisation involved in the process of strategising; and the external actors (for example, consultants, regulators and analysts) who exert influence to shape the realised strategy of an organisation (Jarzabkowski et al. 2007; Jarzabkowski \& Spee 2009:72; Jarzabkowski \& Whittington 2008:282-285; Johnson et al. 2003:14).

\section{Practices}

Strategy practices are the social, symbolic and material tools that practitioners use during the 'doing of strategy'. These include, but are not limited to:

- Strategy models that are used in everyday strategy jargon, such as a swot analysis, the five forces model and the Boston Consulting Group (BCG) growth matrix.

- The material artefacts and technology, such as powerpoint presentations and flipcharts, used in performing the action of strategising.

- The background knowledge of the specific practitioner.

The use of these practices is essential to the doing of strategy and is also known as the cognitive, behavioural, procedural and physical resources that practitioners use to interact with organisational actors in order to accomplish the social activity of strategy (Jarzabkowski et al. 2007; Jarzabkowski \& Spee 2009:71; Jarzabkowski \& Whittington 2008:282; Johnson et al. 2003).
Given the nearly unlimited number of combinations between the three elements of strategising DNA, namely praxis, practitioner and practice, Jazarbkowski and Spee (2009:74) constructed a typology matrix aimed at providing research parameters for the S-as-P research field around two of these elements, namely, praxis and practitioner.

\section{The Jazarbkowski and Spee (2009) typology matrix}

The Jazarbkowski and Spee (2009:74) typology matrix was constructed following an extensive review of literature around two of the three key elements of the S-as-P DNA, namely, praxis and practitioner. Praxis is where action and operation meet, the flow of activity between society and what individual people are doing (Sztompka 1991:96). Praxis refers to the reasoning behind the practice or the phenomenon that the researcher is trying to explain. More specifically: microlevel praxis seeks to explain strategic reasoning at individual or group level, meso-level praxis is pitched at organisational and sub-organisational level, and macro-level praxis includes research that seeks to explain strategy praxis at institutional and industry level.

Strategy practitioners were also grouped into three groups, namely, individual, internal practitioners; aggregate (groups) practitioners within the organisation; and external aggregate practitioners. The nine domains, domain A to I, which together constitute the Jazarbkowski and Spee (2009:69) typology matrix, are as follows.

\section{Domain A}

Domain A includes those studies that have examined individual actors, focusing on micro-level praxis. These papers typically focus on an individual's experience and how this impacts on the strategising abilities of the individual. In illustrating the nature of domain A research, Jarzabkowski and Spee (2009:75) propose the following broad research question whilst indicating that this question could be studied from multiple angles: 'What are the strategy implications in the way John, the CEO, and Sally, the CFO, negotiate over a particular strategic target?' Research that was carried out in this domain includes, but is not limited, to Cornelissen, Mantere and Vaara (2014:699) who investigated how the strategic outcome of an event was impacted by the way in which it was framed by various individuals, and Vaara and Pedersen (2014:593) who investigated how strategy narratives (stories) enabled or constrained the strategic sense-making of individuals.

\section{Domain B}

Domain B includes those studies that have examined individual actors, focusing on meso-level praxis. Domain B papers mostly focus on how the activities of individuals shape organisational strategy. The following broad research question is used to illustrate the nature of domain B research: 'What are the implications of the interactions between the six members of a project team for implementing the new strategic direction?' 
(Jarzabkowski \& Spee 2009:76). An example of a paper that falls within this domain is the work carried out by Ma, Seidl and Guérard (2014), where the CEO post-succession process was investigated.

\section{Domain C}

Domain $C$ includes those studies that have examined individual actors, focusing on macro-level praxis. These studies often seek to explain institutional, market or industry actions from the individual's perspective. Vaara, Kleymann and Seristö's (2004) study, that explained how alliances became a legitimate strategy within the airline industry, is used as an example of domain $C$ research. The researchers drew upon a pool of multi-level airline employees from several airlines and examined how individual specific action influenced the establishment of alliances as the dominant form of competition in the airline industry.

\section{Domain D}

Domain D includes those studies that have examined aggregate actors (grouped according to position or function), focusing on micro-level praxis. The following broad research question is proposed as an illustration of the nature of domain D research: 'How do the interactions between top and middle management within a strategy workshop, shape the conduct and outcome of that workshop?' (Jarzabkowski \& Spee 2009:77). The most recent paper in domain $\mathrm{D}$, to be included on the S-as-P official bibliography, is that of Demir (2015:S125) who investigated how strategy actors, notwithstanding their physical absence, inculcate strategic behaviour in organisations.

\section{Domain E}

Domain E includes those studies, which focus on meso-level praxis, that have examined only one or multiple classes of aggregate actors, often comparing the influence of different classes on organisational strategy. In illustrating the nature of domain E research, Jarzabkowski and Spee (2009:78) propose the following broad research question: 'How does the Praxis of different business units in implementing an organisationwide change program, influence their perceptions of the success of that program?' Domain E is eloquently illustrated by the work of Balogun, Best and Lê (2015:1285) who investigated how the actions of frontline workers influence the realised strategy of the organisation.

\section{Domain F}

Domain F includes those studies that have examined aggregate actors within the organisation and macro-level praxis. The following broad research question is proposed as an illustration of the nature of domain $F$ research: 'How do executive directors in retail firms take account of an attempt to influence the industry analyses that shape investment in their industry?' (Jarzabkowski \& Spee 2009:78).

\section{Domain G}

Domain $G$ includes those studies that have examined how external aggregate actors shape micro-level praxis. Domain G studies, for example, include, but are not limited to, studies that examine the influence of strategy consultants on the praxis of strategy workshops. McKinlay et al. (2010:1012) conducted research in this domain when they investigated the impact of Foucault's concept of governmentality on understanding strategy.

\section{Domain H}

Domain $\mathrm{H}$ includes those studies that focus on the relationship between external aggregate actors and strategy praxis at mesolevel. The following illustrative research question brings domain $\mathrm{H}$ into focus: 'What practices do environmental groups draw upon in an attempt to influence the inclusion of environmental considerations within an oil company's strategy?' (Jarzabkowski \& Spee 2009:80).

\section{Domain I}

Domain I includes those studies that focus on the relationship between external aggregate actors and macro-level praxis. In illustrating the focus of domain I research, the following research question is proposed: 'Do banks' formal borrowing requirements shape strategic plans and planning procedures of small-and-medium-sized enterprises (SMEs) and, if so, in what ways?' (Jarzabkowski \& Spee 2009:80). Domain I research is best illustrated by Vaara (2014:500) who aimed to enlighten scholars to the '... discursive and ideological underpinnings of the social, political and financial crisis in Greece and other European countries'.

\section{Research methodology}

Approached from an interpretivist paradigm and triggered by practical experience, this article is aimed at updating the Jarzabkowski and Spee (2009) S-as-P typology matrix. A content analysis was conducted of all papers listed on the bibliography of the official S-as-P website. The researchers obtained the original versions of the papers and scrutinised the information contained in the abstracts (if information on practice and or praxis was not indicated in the abstract, the methodology section was consulted) and titles. When the praxis and practitioner of each paper was identified, this together with the names of the papers and researchers, as well as the paper's key words were inputted as data into an Excel document. This data were subsequently characterised and counted.

The typology matrix was updated by conducting a qualitative study which included a critical evaluation, classification and autonomous count (Hannah \& Lautsch 2010:16) of the 394 works included in the official S-as-P bibliography. The analysis of the papers on the S-as-P website was conducted separately by the researchers and research assistants. The various analyses were then combined into the final dataset used and reported herein. The works were first evaluated 
against the set of criteria listed below. Inclusion criteria formed the baseline against which papers were screened, whilst the exclusion criterion enabled the accurate reflection of the current S-as-P research gap, where as such, a paper was only included in the comparative typology matrix if:

- It is listed on the official S-as-P Bibliography (Strategy-aspractice International Network 2015).

- The researchers could identify a strategy practitioner.

- The identified practitioner was a legal or a natural person; inanimate objects, such as strategic plans were not considered practitioners.

- Academic works were published from 2008 to 2015.

- Papers were not methodological in nature, meaning that they addressed only the research methodology or the $\mathrm{S}$-as-P research agenda, used in S-as-P research.

- The paper was published in an academic, peer reviewed journal (academic works published in thesis and textbook were not considered).

- The paper was published in English.

Of the 394 academic works that appear in the official S-as-P Bibliography, 268 were published between 2008 and 2015. Of the 268,77 works adhered to the above-mentioned criteria that the research used to include works in the comparative typology matrix. Three of the works counted in the original typology matrix were published within the 2008 to 2015 time limit, but as these works did not adhere to the other criteria, they were excluded from further analysis. The classification of works into domains was carried out separately by both the researchers, with the help of two research assistants. Results were compared and where there were differences, an independent, expert third party was consulted and consensus was reached. The nine domains are seen as distinct separate areas of research, but are not considered to be mutually exclusive; as such, some works appear in more than one domain, and these works have been counted in each of the applicable domains. This is again in line with the methodology used by Jarzabkowski and Spee (2009:70), wherein overlapping papers were counted in both domains.

In order to establish the publication pattern for the 2008 to 2015 period, an autonomous count (again counted separately by the researchers and research assistants) was conducted of the classified papers, and the original typology matrix was updated to reflect the count (Hannah \& Lautsch 2010:16). The papers that were counted and included in the updated matrix, the count included classifying each paper based on the domain in which they fell, whether they make empirical or theoretical contributions as well as the practitioners and the praxis investigated are summarised in Table 1.

A thematic analysis of the practitioners and praxis, tabled in Table 1, revealed that $25 \%$ of the papers counted in the comparative typology matrix focused on the activities of managers/executives and $34 \%$ of the papers focused on different aspects of the strategising process.

The 2015 count of the papers included in Table 1 revealed that eight papers were classified as falling into domain E, and compared to the 2009 count where 16 papers were classified as falling into domain E, indicating a 50\% decline in research into this domain. Domain A, B and I are represented by three papers each, domain G by two, and finally, domain $\mathrm{F}$ is represented by one. The final number of theoretical and empirical papers counted in each domain is included in the comparative typology matrix.

Considering that $76 \%$ of the papers in Table 1 was characterised as in domain $\mathrm{D}$, further inspection into this domain became necessary. Through the closer inspection of a purposeful sample of eight papers in domain D, the researchers looked for patterns in the research shown in domain D. The sample included the first paper appearing in the official S-as-P bibliography in each year for the period 2008 to 2015 (the sample of papers that have been analysed are reflected in Table 2). As per the S-as-P research parameters, the sample of papers do indeed all contribute to the accumulation of context-dependent knowledge and are able to delineate the complex social phenomenon of strategising. Moreover, the value of the practical knowledge gained in the sampled papers appears constrained by its general application because of the scope of research in this domain. Domain D research focuses on aggregate actors and micro-level praxis (Jarzabkowski \& Spee 2009:77).

\section{Comparative findings}

Words like strategy, strategising and strategic are widely used in contemporary society to emphasise the importance of many things. This colloquial use of the word strategy necessitates the defining of strategy, as viewed through the sociological eye (Hughes 1971:5; Whittington 2007:1575, 1577) of S-as-P researchers. In the sociological view, strategy is defined as 'something that people do (an activity) with stuff in society', whilst strategising refers to the actions that people take and the practices they use in accomplishing the activity of strategy (Chia \& MacKay 2007:218; Jarzabkowski \& Spee 2009:69; Jarzabkowski \& Whittington 2008:282; Whittington 2002:C3-C5).

The activity of strategy, or rather the activities that strategists use in combination with various activities in the process of strategising, is what S-as-P, as a subfield of strategy research, seeks to explain (Strategy-as-Practice International Network 2015). Considering that of the 77 works that adhered to the above-mentioned criteria and which were included in the comparative typology matrix, 59 (see Table 3 ) were categorised as being in domain D (internal aggregate actors, focusing on micro-level praxis), it appears that S-as-P research has become foreseeable, focusing only on the activities of groups of actors within the organisation. This is graphically depicted in Figure 3 and Figure 4 below.

The number of papers assigned to each domain is used to indicate the contribution of research papers to the field of S-as-P. The counts show that there has been a shift in the $\mathrm{S}$-as-P research focus in the last six years, from focusing on domain E in the 2009 Jarzabkowski and Spee (2009:74) count, 
TABLE 1: List of works counted in updated strategy-as-practice typology matrix.

\begin{tabular}{|c|c|c|c|c|}
\hline Citation & Domain & $\begin{array}{c}\text { Theoretical/ } \\
\text { empirical }\end{array}$ & Practitioner & Praxis \\
\hline Balogun et al. 2015:1285 & $\mathrm{E}$ & $\mathrm{E}$ & Frontline workers & Realised strategy \\
\hline Demir 2015:S125 & $\mathrm{D}$ & $E$ & Strategy actors & Affordances \\
\hline Jarzabkowski \& Lê 2015:Abstract & $\mathrm{D}$ & E & Organisational actors & Paradox \\
\hline Schmachtel 2015: Abstract & 1 & $\mathrm{E}$ & Partnerships & Discourse \\
\hline Laine et al. 2015: Abstract & $E$ & $\mathrm{E}$ & Strategists & Performance identity \\
\hline Cornelissen et al. 2015:10 & $\mathrm{E}$ & T & Institutions & Communication \\
\hline Kroon, Cornelissen \& Vaara 2015:775 & E & E & Multi-National Corporations & Language \\
\hline Laamanen, Lamberg \& Vaara 2015: Abstract & D & $\mathrm{E}$ & Management team & Management learning \\
\hline Joutsenvirta \& Vaara 2015:741 & D & E & Project team & Discursive legitimisation \\
\hline Menz \& Scheef 2014:461 & $\mathrm{D}$ & $\mathrm{E}$ & Chief strategy officers & Antecedents and performance consequences \\
\hline Sorsa, Pälli \& Mikkola 2014:56 & D & $\mathrm{E}$ & Managers & Discourses in performance appraisal interviews \\
\hline Abdallah \& Langley $2014: 235,240$ & A & $\mathrm{E}$ & A top manager & Ambiguity \\
\hline Dameron \& Torset 2014:291 & D & E & Strategy practitioners & Tensions \\
\hline Healey et al. 2015:507 & D & E & Workshop participants & Effectiveness \\
\hline Ma et al. $2014: 460$ & B & $\mathrm{E}$ & CEO & The post-succession process \\
\hline Cornelissen et al. 2014 & A & $\mathrm{E}$ & The individual & Sense-making \\
\hline Vaara 2014:500 & 1 & $\mathrm{E}$ & Media & Legitimisation \\
\hline Vaara \& Pedersen 2014:593 & A & $\mathrm{T}$ & Practitioners & Strategy narratives \\
\hline Sugarman 2014:141 & D & $\mathrm{E}$ & The individual & Dynamic capabilities \\
\hline Peltokorpi \& Vaara 2014:600 & D & $\mathrm{T}$ & Multi-National Corporations & Language-sensitive recruitment \\
\hline Vaara et al. 2014:1302 & $\mathrm{D}$ & $\mathrm{E}$ & Managers & Merger and acquisition performance \\
\hline Baeta, Brito \& Souza 2014:17 & $E$ & $\mathrm{E}$ & Public universities & Discourse \\
\hline Mueller et al. 2013:1168 & D & $\mathrm{E}$ & Senior managers & Sense-making of politics \\
\hline Salih \& Doll 2013:32 & D & $\mathrm{E}$ & Middle managers & Strategy implementation \\
\hline Vesa \& Franck 2013:23 & D & $\mathrm{E}$ & Managers & Temporality of strategy \\
\hline Jarzabkowski, Lê \& Van de Ven 2013:245 & D & $\mathrm{E}$ & Managers & Coping mechanisms \\
\hline Jarzabkowski, Spee \& Smets 2013:41 & $\mathrm{D}$ & $\mathrm{E}$ & Underwriting managers & Material artefacts \\
\hline Paroutis \& Heracleous 2013:935 & D & $\mathrm{E}$ & Strategy directors & First-order strategy discourse \\
\hline Kuepers, Mantere \& Statler 2012:83 & $\mathrm{D}$ & $\mathrm{E}$ & Non-senior stakeholders & Story telling \\
\hline Pretorius \& Stander 2012:11963 & G & $\mathrm{T}$ & Consultants & Strategising process \\
\hline Rouleau \& Balogun 2011:953 & D & E & Middle managers & Enactment of strategic roles \\
\hline Denis et al. 2011:225 & D & $\mathrm{E}$ & Strategic decision makers & Escalating indecision \\
\hline Mantere, Schildt \& Sillince 2011:172 & $\mathrm{D}$ & $\mathrm{E}$ & Managers & Change management \\
\hline Vaara \& Tienari 2011:370 & $\mathrm{E}$ & $\mathrm{E}$ & Ante-narratives & Change management \\
\hline Kaplan 2011:320 & $\mathrm{D}$ & E & Managers & Strategy making \\
\hline Spee \& Jarzabkowski 2011:1217 & B & E & Individual actors & Strategic planning \\
\hline Kornberger \& Clegg 2011:136 & $\mathrm{D}$ & E & City of Sydney & Strategy-making process \\
\hline Ludwig \& Pemberton 2011:215 & D & E & Practitioners & Dynamic capabilities \\
\hline van Wessel, van Buuren \& van Woerkum 2011:262 & D & E & Water managers & Strategising \\
\hline Corbett-Etchevers \& Mounoud 2011:165 & D & $\mathrm{E}$ & Organisation & Management ideas \\
\hline Lavarda, Giner \& Bonet 2011:86 & $\mathrm{D}$ & $\mathrm{E}$ & Organisation & Strategy formulation \\
\hline Abdallah, Denis \& Langley 2011:333 & D & $\mathrm{E}$ & Change leaders & Transcendent discourse \\
\hline Johnson et al. 2010:1589 & D & $\mathrm{E}$ & Chief executive officers & Strategy workshop dynamics \\
\hline Vaara, Sorsa \& Pälli 2010:685 & D & $\mathrm{E}$ & City of Lahti & Strategic planning \\
\hline Denis, Langley \& Rouleau 2010:67 & D & E & Leaders & Leadership \\
\hline Fauré et al. 2010:1249 & D & E & Accounting department & Accounting process \\
\hline Stensaker \& Langley 2010:7 & $\mathrm{E}$ & E & Multi divisional & Change management \\
\hline Sugarman 2010:157 & D & E & New York Police Department & Organisational learning \\
\hline McKinlay et al 2010:1012 & G & T & Managers & Strategy conceptualisation / governmentality \\
\hline Suominen \& Mantere 2010:211 & D & E & Managers & Strategy consumption \\
\hline Erkama \& Vaara 2010:813 & $\mathrm{D}$ & $\mathrm{E}$ & Negotiation team & Restructuring \\
\hline Vaara \& Monin 2010:3 & D & $\mathrm{E}$ & Various actors & Legitimisation \\
\hline Lavarda, Canet-Giner \& Peris-Bonet 2010:358 & D & $\mathrm{E}$ & Middle managers & Strategy formulation \\
\hline Jarratt \& Stiles 2010:28 & D & E & Senior executives & Strategising practices \\
\hline Hendry, Kiel \& Nicholson 2010:33 & $\mathrm{D}$ & E & Board & Strategising \\
\hline Jarzabkowski \& Balogun 2009:1255 & D & $\mathrm{E}$ & Strategy participants & Strategic planning / integration \\
\hline
\end{tabular}


TABLE 1 (Continues...): List of works counted in updated strategy-as-practice typology matrix.

\begin{tabular}{|c|c|c|c|c|}
\hline Citation & Domain & $\begin{array}{c}\text { Theoretical/ } \\
\text { empirical }\end{array}$ & Practitioner & Praxis \\
\hline Angwin, Paroutis \& Mitson 2009:74 & $\mathrm{D}$ & $E$ & Senior strategy executives & Strategic engagement and awareness \\
\hline Pälli, Vaara \& Sorsa 2009:303 & D & E & City of Lahti & Strategic planning \\
\hline Eppler \& Platts 2009:42 & $\mathrm{D}$ & E & Various actors & Visualisation \\
\hline Jarzabkowski 2008:621 & D & $\mathrm{T}$ & Top management & Structuration theory \\
\hline King 2008:345 & D & E & Venture capitalists & Decision-making process \\
\hline Heracleous \& Jacobs 2008b:45 & D & E & Organisational actors & Metaphors \\
\hline Kaplan 2008:729 & $\mathrm{D}$ & E & Managers & Cognitive frames \\
\hline Mantere \& Vaara 2008:341 & $\mathrm{D}$ & E & Various actors emphasis on non-senior & Strategy processes \\
\hline Mantere 2008:294 & $\mathrm{D}$ & $\mathrm{E}$ & Various actors & Strategy processes \\
\hline Nordqvist \& Melin 2008:326 & B & $\mathrm{E}$ & Various actors & Strategic planning champions \\
\hline Ezzamel \& Willmott 2008:191 & D & E & Accounting department & Strategic discourse \\
\hline Heracleous \& Jacobs 2008a:309 & D & $\mathrm{E}$ & Strategists & Metaphors \\
\hline Statler, Jacobs \& Roos 2008:133 & D & E & Senior management & Analogical reasoning \\
\hline Ocasio \& Joseph 2008:248 & D & E & Senior management regime & Strategic planning \\
\hline Voronov 2008:195 & $\mathrm{D}$ & E & Project team & Organisational learning \\
\hline
\end{tabular}

Source: Authors' own work

$E$, refers to empirical papers; $T$, refers to theoretical papers.

TABLE 2: The list of papers included in the domain D sample.

\begin{tabular}{ll}
\hline Year & $\begin{array}{l}\text { First citation in domain D on the official } \\
\text { strategy-as-practice (S-as-P) bibliography }\end{array}$ \\
\hline 2015 & Demir 2015 \\
2014 & Menz \& Scheef 2014 \\
2013 & Mueller et al. 2013 \\
2012 & Wright et al. 2012 \\
2011 & Rouleau \& Balogun 2011 \\
2010 & Johnson et al. 2010 \\
2009 & Jarzabkowski \& Balogun 2009 \\
2008 & Jarzabkowski 2008 \\
\hline
\end{tabular}

Source: Authors' own work

to focusing on domain D in the 2015 count. This is evident in Table 2 and Figure 3 above, with both these sources indicating that the majority of current S-as-P research focuses on domain D (76\%), whilst the Jarzabkowski and Spee (2009:74) count emphasised domain E (46\%). The count variation of the total papers in all the domains is depicted in Figure 5, which clearly shows that there has been a decrease in research into every domain except for domains $G$ and D. Domain I shows a $67 \%$ decrease (Table 3 and Figure 3 ) in the number of papers published. The data (contained in Table 2 and Figure 3) on domain I give interesting insight into this domain. From the data it can be concluded that it is feasible to theorise about domain I, but it is difficult to test the theory empirically, as the eight theoretical papers in this domain did not yield eight empirical papers, but only two.

Figure 4 clearly shows the movement in the focus of the domains between the 2009 and 2015 count. The major shift towards domain D necessitated a closer investigation into the papers published in this domain (please refer to the methodology section for a description of this investigation). For research to be classified as domain D it must investigate micro-level praxis of the aggregate practitioner. This shift in research preference is most likely as a result of the micro-level praxis that defines this domain which makes it much easier to obtain permission to do research within one organisation, and as it involves a group of people, authority is also easier to ensure. On the other hand, there is the threat that this domain may become too micro. Notwithstanding the excellent reach in domain $\mathrm{D}$, the link between domain $\mathrm{D}$ research and organisational performance is mostly missing. Moreover, Johnson et al. (2010:1613) highlight one of the major problems observed in this domain, namely the episodic nature and ritual characteristics of research performed in this domain. Johnson et al. (2010:1590) highlight this in their research when they note that '... all strategy episodes are more or less ritualized' and they explicitly state (Johnson et al. 2010:1612-1613) that this type of research has a limited impact on the formulation of a planned strategy; therefore it has a limited impact on the performance of an organisation.

Considering the dominance of domain D in S-as-P research, it is imperative that one understands the apparent shortcomings of research carried out in this domain. S-as-P research should enable the researcher to move away from the notion that strategy is something an organisation has, towards the notion that strategy is something an organisation does, as illustrated by a preference for domain D research. Domain D research, for the most part, contradicts the methodological guidelines for $\mathrm{S}$-as-P research, as indicated by various researchers. These guidelines differ from researcher to researcher; however, most researchers agree on the following as parameters for 'S-as-P' research (Balogun, Huff \& Johnson 2003; CampbellHunt 2007; Johnson et al. 2003). S-as-P research should:

- Span hierarchical levels within organisations (increased depth).

- Span various organisations (increased breadth).

- Not be too micro, thereby excluding context and becoming un-generalisable.

- Problemise performance by linking micro-activity to macro-results.

- Allow the accumulation of practical knowledge.

As discussed earlier, the inability to problemise performance within domain D research (Johnson et al. 2010:1612-1613) 
TABLE 3: The number of papers counted in each strategy-as-practice (S-as-P) domain

\begin{tabular}{|c|c|c|c|c|c|c|c|}
\hline \multirow[t]{2}{*}{ Domains } & \multicolumn{3}{|c|}{2009} & \multicolumn{3}{|c|}{2015} & \multirow{2}{*}{$\begin{array}{l}\text { Percentage change } \\
\text { from } 2009\end{array}$} \\
\hline & $\eta$ Empirical & $\eta$ Theoretical & Total & $\eta$ Empirical & $\eta$ Theoretical & Total & \\
\hline $\bar{A}$ & 6 & 1 & 7 & 2 & 1 & 3 & $-57.14 \%$ \\
\hline B & 3 & 0 & 3 & 3 & 0 & 3 & $0.00 \%$ \\
\hline c & 1 & 0 & 1 & 0 & 0 & 0 & $-100.00 \%$ \\
\hline D & 6 & 0 & 6 & 56 & 3 & 59 & $883.33 \%$ \\
\hline E & 16 & 0 & 16 & 7 & 1 & 8 & $-50.00 \%$ \\
\hline $\mathrm{F}$ & 1 & 2 & 3 & 1 & 0 & 1 & $-66.67 \%$ \\
\hline G & 0 & 0 & 0 & 0 & 2 & 2 & $-200.00 \%$ \\
\hline $\mathrm{H}$ & 1 & 0 & 1 & 0 & 0 & 0 & $-100.00 \%$ \\
\hline 1 & 1 & 8 & 9 & 2 & 1 & 3 & $-66.67 \%$ \\
\hline
\end{tabular}

Source: Authors' own work

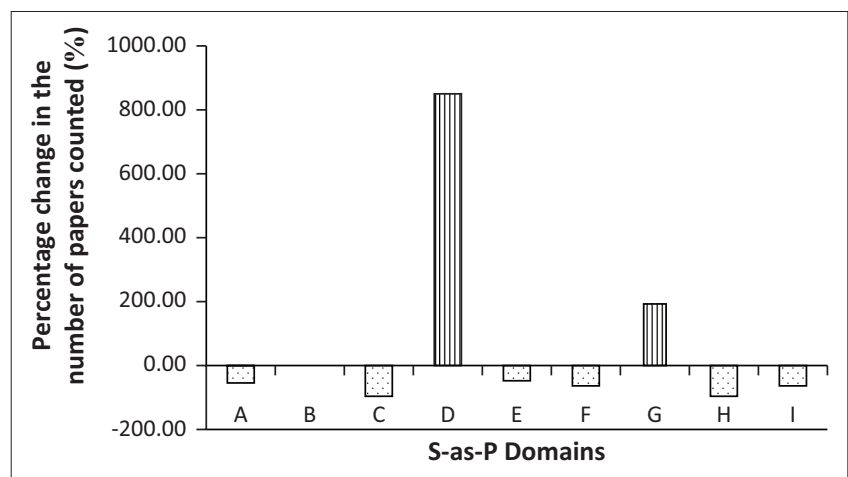

Source: Authors' own work

FIGURE 3: The percentage change in the number of papers counted in the strategy-as-practice) research domains between 2009 and 2015.

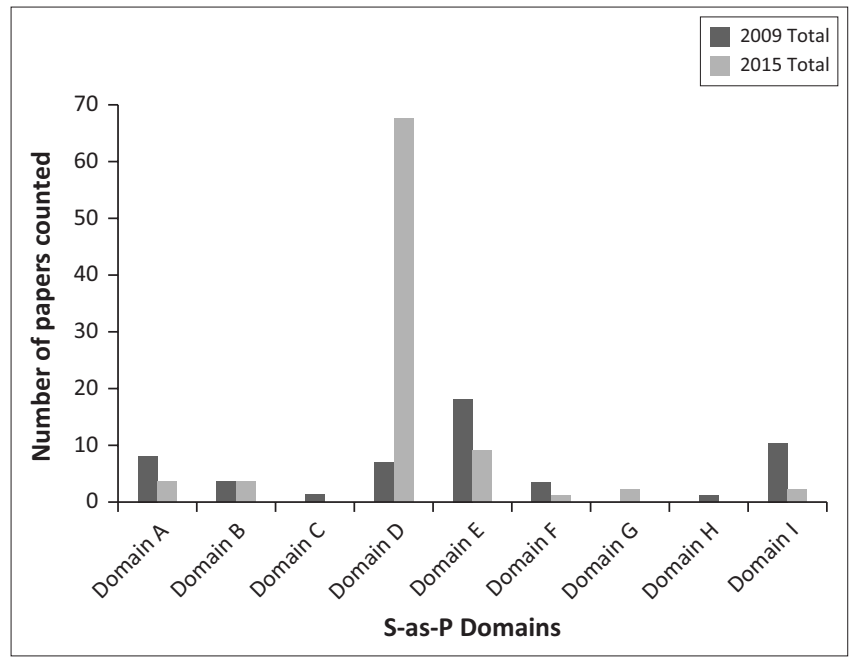

Source: Authors' own work

FIGURE 4: Total number of papers counted, both in 2009 and 2015, in each strategy-as-practice (S-as-P) research domain.

results mainly from an inability to link the societal, contextual (industrial) and/or organisational perspective of strategy to the micro-praxis of this domain. S-as-P researchers must endeavour to select participants that will give their study a broader relevance (Jarzabkowski \& Balogun 2009:1263), thereby avoiding the trap of this domain: triviality. Triviality in terms of the analytical generalisability of the findings of the studies means that if the participants of any study become too micro and situation-specific, there is very little knowledge that can be transferred to the general practice of strategy. The use of aggregate participants further enables

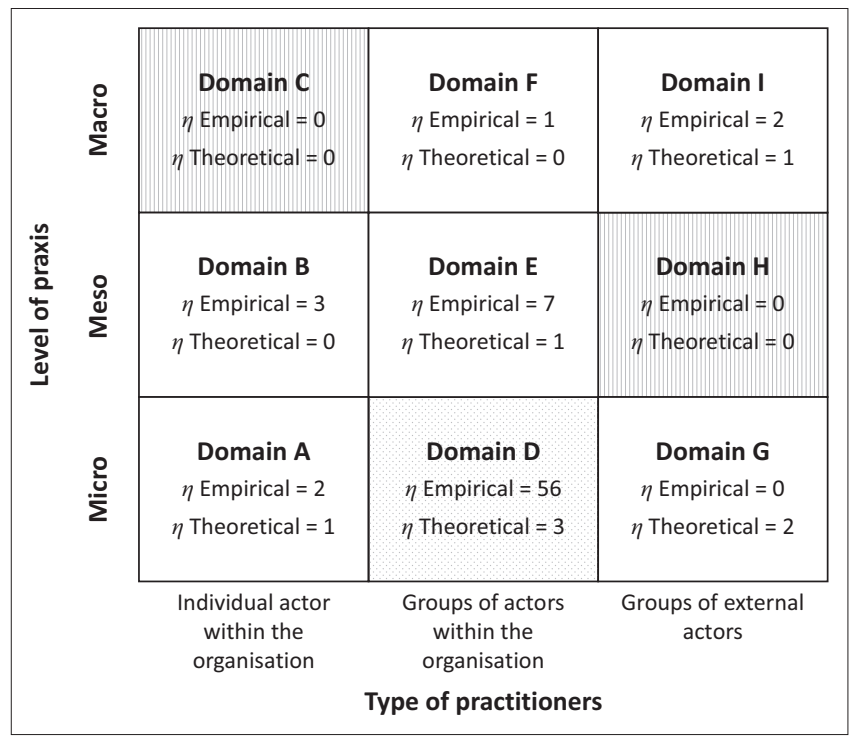

Source: Adapted from Jarzabkowski and Spee (2009:74) typology matrix

FIGURE 5: 2015 Comparative typology matrix of strategy-as-practice research.

research in this domain, as it instils a sense of anonymity with participants, as opposed to, for example, research in domain A, which would include a single case study on the strategising practises of John Doe the CEO of successful company ABC.

Considering the other domains and the methodological guideline of problemising performance, it would, however, appear that the ability to conceptualise research that would be able to address strategy at either the meso- or macro-level remains elusive. This is particularly evident in the lack of reach into domains $\mathrm{C}$ and $\mathrm{H}$. The need for research into these domains is highlighted by Vaara and Whitington (2012:303, 305), who explicitly identify the macro- and meso-levels as needing future S-as-P research. It is therefore hypothesised that the sensitivity of information, and the inevitable imitability of data collected at these levels, could threaten the competitive advantage of organisations participating in research at this level, making it extremely difficult to find participants for research in these domains, and therefore one sees only a limited number of research outputs in this domain.

\section{Comparative matrix}

The purpose of this article was to present the S-as-P researcher with an updated/comparative typology matrix, wherein 
researchers could find a true reflection of the current S-as-P research field. Figure 5 below presents this updated/ comparative matrix, using the same graphical representation as the Jazarbkowski and Spee (2009) S-as-P typology matrix.

\section{Conclusions}

This paper provides the reader with an updated version of the Jarzabkowski and Spee (2009:74) S-as-P typology matrix for the period 2008 to 2015. It is clear from the typology matrix for this period, that relative to other domains, domain $\mathrm{D}$ has been over-researched. The original typology matrix shows that domain $\mathrm{E}$ had received the most research attention at that time. It is clear from the updated matrix that both domains $\mathrm{C}$ and $\mathrm{H}$ have not received any research attention between 2008 and 2015. These domains also received negligible attention in the original matrix, where only one paper per domain was counted.

Considering that $\mathrm{S}$-as-P research is positioned as a research tool which endeavours to explain the doing of strategy, the focus on domain D, without a clear and explicit link to performance and competitive advantage, is effectively divorcing S-as-P from its original objective: to explain the doing of strategy or competitive advantage. An S-as-P scholar will have to directly link the attainment of superior rents and/or competitive advantage to their research questions, in an effort to re-instate S-as-P as a plausible contributor to the strategy debate.

The next step in the S-as-P evolution is most likely embedded in the under-researched domains, specifically domains $C$ and $\mathrm{H}$. In addition, future $\mathrm{S}$-as-P research should focus on how the individual strategist (the individual being the unit of analysis) interacts with, experiences or perceives the organisation's macro environment. Researchers should also focus on how external practitioners, such as management consultants, economists or higher education institutions shape the market environment in which an organisation operates. Moreover, researchers need to find innovative methods of obtaining the data necessary to study the doing of strategy, within the context of the dynamic external environment from which S-as-P research emerged. If researchers fail to do this, S-as-P research will lose the evolutionary battle, and much like the Megalodon and Mako sharks, will merely exist in history books.

\section{Management implications}

Notably, S-as-P research originated from a societal call for a closer link between the theory and practice of strategy (Dameron et al. 2015:S1; Haugstad 1999; Johnson et al. 2003:19; Whittington 2002:C1, 2007:1577). The management of organisations must then avail the organisations to be disseminated into data that will enable S-as-P researchers to make this link at the meso- and macro-level, even if this is carried out anonymously. Failure to do so will force strategy theory to once more become a theoretical economic subject, with no cognisance for the actual doing of strategy.

\section{Limitations and future research}

The research which informed this article was limited to the analysis of papers listed on the official bibliography of the $\mathrm{S}$-as-P website. This bibliography does not claim to list every piece of research carried out within the S-as-P research domain, but relies on researchers to submit their work to the administrator for confirmation. To do so, the S-as-P researcher must first apply for membership of the S-as-P Research Society and only upon acceptance can a paper be submitted. The website administrators will determine if a paper does indeed fall within the scope of S-as-P research, and will subsequently upload approved papers to the website. Future research should extend the scope of the study to include a wider collection of research which will enable a deeper understanding of the state of S-as-P research.

\section{Acknowledgements}

The authors would like to acknowledge the research assistants, Saskia Pretorius and Ireze van Wyk, who assisted with the classification of papers, and the anonymous classification moderator, who helped to solve many puzzles.

\section{Competing interests}

The authors declare that they have no financial or personal relationships which may have inappropriately influenced them in writing this article.

\section{Authors' contributions}

K.S. executed the study independently in partial fulfillment of her PhD under the supervision and oversight of M.P. His contribution was primarily conceptual, he however further partook in the study as a secondary researcher to ensure the validity and trustworthiness of the methodology.

\section{References}

Abdallah, C., Denis, J. \& Langley, A., 2011, 'Having your cake and eating it too: Discourses of transcendence and their role in organizational change dynamics', Journal of Organizational Change Management 24(3), 333-348. http://dx.doi. org/10.1108/09534811111132730

Abdallah, C. \& Langley, A., 2014, 'The double edge of ambiguity in strategic planning', Journal of Management Studies 51(2), 235-264. http://dx.doi.org/10.1111/ joms.12002

All-free-download.com, 2015, DNA Helix, viewed 3 December 2015, from http:// all-free-download.com/free-vector/download/dna_helix_clip_art_16036.html

Angwin, D., Paroutis, S. \& Mitson, S., 2009, 'Connecting up strategy: Are Senior Strategy Directors (SSDs) a missing link?', California Management Review 51(3), 74-94. http://dx.doi.org/10.2307/41166494

Arvidsson, V., Holmström, J. \& Lyytinen, K., 2014, 'Information systems use as strategy practice: A multi-dimensional view of strategic information system implementation and use', The Journal of Strategic Information Systems 23(1), 45-61. http://dx.doi. org $/ 10.1016 / j$.jsis.2014.01.004

Baeta, O., Brito, M. \& Souza, R., 2014, 'Strategy as discursive practice in a Brazilian Public University: A look under the perspective of critical discourse analysis', Public Administration Research 3(2), 17-27. http://dx.doi.org/10.5539/par. v3n2p17

Balogun, J., Best, K. \& Lê, J., 2015, 'Selling the object of strategy: How frontline workers realize strategy through their daily Work', Organization Studies 36(10), 1285. http://dx.doi.org/10.1177/0170840615590282

Balogun, J., Huff, A. S. \& Johnson., P. 2003, 'Three Responses to the Methodological Challenges of Studying Strategizing'. Journal of Management Studies, 40: 197-224. http://dx.doi.org/10.1111/1467-6486.t01-1-00009

Barney, J.B. \& Hesterley, W.S. (2015) Strategic Management and Competitive Advantage: Concepts, 5th Edition. P. 44. Pearson Education, New York. 
Blome, C., Schoenherr, T. \& Eckstein, D., 2014, 'The impact of knowledge transfer and complexity on supply chain flexibility: A knowledge-based view', International Journal of Production Economics 147, 307-316. http://dx.doi.org/10.1016/ j.ijpe.2013.02.028

Campbell-Hunt, C., 2007, 'Complexity in practice', Human Relations 60(5), 793-823. http://dx.doi.org/10.1177/0018726707079202

Carter, C., Clegg, S.R. \& Kornberger, M., 2008, 'Strategy as practice', Strategic Organization 6(1), 83-99. http://dx.doi.org/10.1177/1476127007087154

Chia, R. \& MacKay, B., 2007, 'Post-processual challenges for the emerging strategyas-practice perspective: Discovering strategy in the logic of practice', Human Relations 60(1), 217-242. http://dx.doi.org/10.1177/0018726707075291

Corbett-Etchevers, I. \& Mounoud, E., 2011, 'A narrative framework for management ideas: Disclosing the plots of knowledge management in a multinational company', Management Learning 42(2), 165-181. http://dx.doi.org/10.1177/ company', Managem

Cornelissen, J.P., Durand, R., Fiss, P.C., Lammers, J. C. \& Vaara, E., 2015, 'Putting communication front and center in institutional theory and analysis', Academy of Management Review 1(40), 10-27. http://dx.doi.org/10.5465/amr.2014.0381

Cornelissen, J.P., Mantere, S. \& Vaara, E., 2014, 'The contraction of meaning: The combined effect of communication, emotions, and materiality on sensemaking in the Stockwell shooting', Journal of Management Studies 51(5), 699-736. http:// dx.doi.org/10.1111/joms.12073

Dameron, S., Lê, J. \& LeBaron, C., 2015, 'Materializing strategy, strategizing materials', British Journal of Management 26(Issue Supplement S1), S1-S12.

Dameron, S. \& Torset, C., 2014, 'The discursive construction of strategists' subjectivities: Towards a paradox lens on strategy', Journal of Management Studies 51(2), 291-319. http://dx.doi.org/10.1111/joms.12072

Demir, R., 2015, 'Strategic activity as bundled affordances', British Journal of Management 26(1), S125-S141. http://dx.doi.org/10.1111/1467-8551.12083

Denis, J., Dompierre, G., Langley, A. \& Rouleau, L., 2011, 'Escalating indecision: Between reification and strategic ambiguity', Organization Science 22(1), 225-244. http://dx.doi.org/10.1287/orsc.1090.0501

Denis, J., Langley, A. \& Rouleau, L., 2010, 'The practice of leadership in the messy world of organizations', Leadership 6(1), 67-88. http://dx.doi.org/10.1177/ 1742715009354233

Dutta, D.K., 2015, 'Hypercompetitive environments, coopetition strategy, and the role of complementary assets in building competitive advantage: Insights from the resource-based view', Strategic Management Review 9(1), 1-11.

Ehret, D.J., Macfadden, B.J., Jones, D.S., DeVries, T.J., Foster, D.A. \& Salas-Gismondi, R., 2012, 'Origin of the white shark Carcharodon (Lamniformes: Lamnidae) based on recalibration of the Upper Neogene Pisco Formation of Peru', Palaeontology on recalibration of the Upper Neogene Pisco Formation of Peru', Palae
55(6), 1139-1153. http://dx.doi.org/10.1111/j.1475-4983.2012.01201.x

Eppler, M.J. \& Platts, K.W., 2009, 'Visual strategizing the systematic use of visualization in the strategic-planning process', Long Range Planning 42(1), 42. http://dx.doi. in the strategic-planning proc
$\mathrm{org} / 10.1016 / \mathrm{j}$. Irp.2008.11.005

Erkama, N. \& Vaara, E., 2010, 'Struggles over legitimacy in global organizational restructuring: A rhetorical perspective on legitimation strategies and dynamics in a shutdown case', Organization Studies 31(7), 813-839. http://dx.doi.org/ 10.1177/0170840609346924

Ezzamel, M. \& Willmott, H., 2008, 'Strategy as discourse in a global retailer: A supplement to rationalist and interpretive accounts', Organization Studies 29(2), 191-217. http://dx.doi.org/10.1177/0170840607082226

Fahy, K.M., Easterby-Smith, M. \& Lervik, J.E., 2014, 'The power of spatial and temporal orderings in organizational learning', Management Learning 45(2), 123. http:// dx.doi.org/10.1177/1350507612471925

Fauré, B., Brummans, B., Giroux, H. \& Taylor, J.R., 2010, 'The calculation of business, or the business of calculation? Accounting as organizing through everyday
communication', Human Relations 63(8), 1249-1273. http://dx.doi.org/10.1177/ communication', Huma

Ferlie, E., Crilly, T. Jashapara, A., Trenholm, S., Peckham, A. \& Currie, G., 2015 'Knowledge mobilization in healthcare organizations: A view from the resourcebased view of the firm', International Journal of Health Policy and Management based view of the firm', International Journal of Health Polic
$4(3), 127-130$. http://dx.doi.org/10.15171/ijhpm.2015.35

Hannah, D.R. \& Lautsch, B.A., 2010, 'Counting in qualitative research: Why to conduct it, when to avoid it, and when to closet it', Journal of Management Inquiry 20(1) 14-22. http://dx.doi.org/10.1177/1056492610375988

Hardy, C. \& Thomas, R., 2014, 'Strategy, discourse and practice: The intensification of power', Journal of Management Studies 51(2), 320-348. http://dx.doi. org/10.1111/joms.12005

Haugstad, B., 1999, Strategy Theory: A short review of literature, viewed 7 Decembe 2015, from http://m.03964.com/read/ac7c84cf4b9618e52d77ab36.html

Healey, M.P., Hodgkinson, G.P., Whittington, R. \& Johnson, G., 2015, 'Off to plan or out to lunch? Relationships between design characteristics and outcomes of strategy workshops', British Journal of Management 26(3), 507-528. http://dx.doi. org/10.1111/1467-8551.12038

Hendry, K.P., Kiel, G.C. \& Nicholson, G., 2010, 'How boards strategise: A strategy as practice view', Long Range Planning 43(1), 33-56. http://dx.doi.org/10.1016/ practice view',
j.Irp.2009.09.005

Heracleous, L. \& Jacobs, C.D., 2008a, 'Crafting strategy - The role of Embodied Metaphors', Long Range Planning 41(3), 309-325. http://dx.doi.org/10.1016/ j.Irp.2008.02.011

Heracleous, L. \& Jacobs, C.D., 2008b, 'Understanding organizations through embodied metaphors', Organisation Studies 29(1), 45-78. http://dx.doi.org/10.1177/ 0170840607086637

Hughes, E.C., 1971, The sociological eye: Selected papers, Aldine-Atherton, Chicago, IL.
Jarratt, D. \& Stiles, D., 2010, 'How are methodologies and tools framing managers' strategizing practice in competitive strategy development?', British Journal of Management 21(1), 28-43. http://dx.doi.org/10.1111/j.1467-8551.2009.00665.x

Jarzabkowski, P., 2008, 'Shaping strategy as a structuration process', Academy of Management Journal 51(4), 621-650.

Jarzabkowski, P. \& Balogun, J., 2009, 'The practice and process of delivering integration through strategic planning', Journal of Management Studies 46(8), 1255-1288. http://dx.doi.org/10.1111/j.1467-6486.2009.00853.x

Jarzabkowski, P., Balogun, J. \& Seidi, D., 2007, 'Strategising: The challenges of a practice perspective', Human Relations 60(5), 5-27. http://dx.doi.org/10.1177/ 0018726707075703

Jarzabkowski, P. \& Lê, J., 2015, 'We have to do this and that? You must be joking: Constructing and responding to paradox through humor', Organisation Studies, published before print, viewed 7 December 2015, from http://www.researchgate. net/profile/Paula Jarzabkowski/publication/282358950 We Have to do This and That You Must be Joking. Constructing and Responding_to_Paradox and_That_You_Must_be_Joking._Constructing_and_Respo
through_Humour/links/560e5e0e08ae0fc513ed2cd7.pdf

Jarzabkowski, P., Lê, J.K. \& Van de Ven, A.H., 2013, 'Responding to competing strategic demands: How organizing, belonging, and performing paradoxes coevolve', Strategic Organization 11(3), 245-280. http://dx.doi.org/10.1177/ 1476127013481016

Jarzabkowski, P. \& Spee, A.P., 2009, 'Strategy-as-practice: A review and future directions for the field', International Journal of Management Reviews 11(1) 69-95. http://dx.doi.org/10.1111/j.1468-2370.2008.00250.x

Jarzabkowski, P., Spee, A.P. \& Smets, M., 2013, 'Material artifacts: Practices for doing strategy with stuff', European Management Journal 31(1), 41-54. http://dx.doi. org/10.1016/j.emj.2012.09.001

Jarzabkowski, P. \& Whittington, R., 2008, 'A strategy-as-practice approach to strategy research and education', Journal of Management Inquiry 17(4), 282-286. http:// dx.doi.org/10.1177/1056492608318150

Johnson, G., Melin, L. \& Whittington, R., 2003, 'Guest editors introduction: Micro strategy and strategizing: Towards an activity-based view', Journal of Management Studies Guest Editors Edition 40(1), 3-22. http://dx.doi.org/10.1111/1467-6486. t01-2-00002

Johnson, G., Prashantham, S., Floyd, S.W. \& Bourque, N., 2010, 'Ritualization of strategy workshops', org/10.1177/0170840610376146

Joutsenvirta, M. \& Vaara, E., 2015, 'Legitimacy struggles and political corporate social responsibility in international settings: A comparative discursive analysis of a contested investment in Latin America', Organization Studies 36(6), 741-777. http://dx.doi.org/10.1177/0170840615571958

Kaplan, S., 2008, 'Framing contests: Strategy making under uncertainty', Organization Science 19(5), 729-752. http://dx.doi.org/10.1287/orsc.1070.0340

Kaplan, S., 2011, 'Strategy \& PowerPoint: An inquiry into the epistemic culture and machinery of strategy making', Organization Science 22(2), 320-346. http:// machinery of strategy making', Orgar
dx.doi.org/10.1287/orsc.1100.0531

King, B.L., 2008, 'Strategizing at leading, venture capital firms: Of planning, opportunism and deliberate emergence', Long Range Planning 41(3), 345-366. http://dx.doi.org/10.1016/j.Irp.2008.03.006

Kornberger, M. \& Clegg, S., 2011, 'Strategy as performative practice: The case of Sydney 2030', Strategic Organization 9(2), 136-162. http://dx.doi.org/10.1177/ 1476127011407758

Kroon, D., Cornelissen, J. \& Vaara, E., 2015, 'Explaining employees' reactions towards a cross-border merger: The role of English language fluency', Management International Review 55(6), 775-800. http://dx.doi.org/10.1007/s11575-015 0259-2

Kuepers, W., Mantere, S. \& Statler, M., 2012, 'Strategy as storytelling: A phenomenological collaboration', Journal for Management Inquiry 22(1), 83-100. phenomenological collaboration', Journal for M
http://dx.doi.org/10.1177/1056492612439089

Kwon, W., Clarke, I. \& Wodak, R., 2009, 'Organizational decision-making, discourse, and power: Integrating across contexts and scales', Discourse and Communication 3(3), 273-302. http://dx.doi.org/10.1177/1750481309337208

Laamanen, T., Lamberg, J.A. \& Vaara, E., 2015. 'Explanations of success and failure in management learning: What can we learn from Nokia's rise and fall?', Academy of Management Learning and Education, published ahead of print, viewed 8 December 2015, from http://amle.aom.org/content/early/2015/01/06/amle. 2013.0177.short

Laine, P.M., Meriläinen, S., Tienari, J. \& Vaara, E., 2015, 'Mastery, submission, and subversion: On the performative construction of strategist identity', Organization Science, published ahead of print, viewed 8 December 2015, from http://org. sagepub.com/content/early/2015/04/08/1350508415575629.abstract

Lavarda, R., Canet-Giner, T. \& Peris-Bonet, F., 2010, 'How middle managers contribute to strategy formation process: Connection of strategy processes and strategy practices', RAE - Revista de Administração de Empresas - São Paulo 50(4), 358-370. http://dx.doi.org/10.1590/S0034-75902010000400002

Lavarda, R.A., Giner, M.T. \& Bonet, F.J., 2011, 'Understanding how the strategy formation process interacts with the management of complex work', European
Business Review 23(1), 71-86. http://dx.doi.org/10.1108/09555341111097991

Liu, F. \& Maitlis, S., 2014, 'Emotional dynamics and strategizing processes: A study of 51(2), 202-234. http://dx.doi.org/10.1111/j.1467-6486.2012.01087.x

Ludwig, G. \& Pemberton, J., 2011, 'A managerial perspective of dynamic capabilities in emerging markets: The case of the Russian steel industry', Journal for East European Management Studies 16(3), 215-236.

Ma, S., Seidl, D. \& Guérard, S., 2014, 'The new CEO and the post-succession process: An integration of past research and future directions', International Journal of Management Reviews 17(4), 460-482. http://dx.doi.org/10.1111/ijmr.12048 
Mantere, S., 2008, 'Role expectations and middle managers strategic agency', Journal of Management Studies 45(2), 294-316.

Mantere, S., Schildt, H. \& Sillince, J.A., 2011, 'Reversal of strategic change', Academy of Management Journal 55(1) 172-196. http://dx.doi.org/10.5465/amj.2008. 0045

Mantere, S. \& Vaara, E., 2008, 'On the problem of participation in strategy: A critical discursive perspective', Organization Science 19(2), 341-358. http://dx.doi.org/ 10.1287 /orsc. 1070.0296

McKinlay, A., Carter, C., Pezet, E. \& Clegg, S., 2010, 'Using Foucault to make strategy. Accounting', Auditing and Accountability Journal 23(8), 1012-1031. http://dx.doi. org/10.1108/09513571011092538

Menz, M. \& Scheef, C., 2014, 'Chief strategy officers: Contingency analysis of thei presence in top management teams', Strategic Management Journal 35(3), 461-471. http://dx.doi.org/10.1002/smj.2104

Molloy, J.C. \& Barney, J.B., 2015, 'Who captures the value created with human capital? A market-based view', The Academy of Management Perspectives 29(3), 309-325. http://dx.doi.org/10.5465/amp.2014.0152

Mueller, F., Whittle, A., Gilchrist, A. \& Lenney, P., 2013, 'Politics and strategy practice: An ethnomethodologically-informed discourse analysis perspective', Business History 55(7), 1168-1199. http://dx.doi.org/10.1080/00076791.2013.838037

Nayak, A., 2008, 'Experiencing creativity in organisations: A practice approach', Long Range Planning 41(4), 420-439. http://dx.doi.org/10.1016/j.Irp.2008.05.001

Nordqvist, M. \& Melin, L., 2008, 'Strategic planning champions: Social craftspersons, artful interpreters and known strangers', Long Range Planning 41(3), 326-344. http://dx.doi.org/10.1016/j.Irp.2008.02.007

Ocasio, W. \& Joseph, J., 2008, 'Rise and fall - Or transformation? The evolution of strategic planning at the General Electric Company, 1940-2006', Long Range Planning 41(3), 248-272. http://dx.doi.org/10.1016/j.Irp.2008.02.010

Paladino, A., Welding, R. \& Whitwell, G., 2015, 'Internal and external organisational orientations: Comparing the resource based view and market orientation', in A.K. Manrai \& H.L. Meadow (eds.), Global perspectives in marketing for the 21st century, p. 338, Springer International Publishing, Switzerland.

Pälli, P., Vaara, E. \& Sorsa, V., 2009, 'Strategy as text and discursive practice: A genrebased approach to strategizing in city administration', Discourse and Communication 3(3), 303-318. http://dx.doi.org/10.1177/1750481309337206

Paroutis, S. \& Heracleous, L., 2013, 'Discourse revisited: Dimensions and employmen of first-order strategy discourse during institutional adoption', Strategic Management Journal 34(8), 935-956. http://dx.doi.org/10.1002/smj.2052

Peltokorpi, V. \& Vaara, E., 2014, 'Knowledge transfer in multinational corporations: Productive and counterproductive effects of language-sensitive recruitment' Journal of International Business Studies 45(5), 600-622. http://dx.doi.org/ 10.1057/jibs.2014.1

Pretorius, M. \& Stander, K., 2012, 'The identification of management consultant liabilities during strategizing', African Journal of Business Management 6(50), 11963-11975. http://dx.doi.org/10.5897/AJBM12.549

Rouleau, L. \& Balogun, J., 2011, 'Middle managers, strategic sensemaking and discursive competence', Journal of Management Studies 48(5), 953-983. http:// dx.doi.org/10.1111/j.1467-6486.2010.00941.x

Salih, A. \& Doll, Y., 2013, 'A middle management perspective on strategy implementation', International Journal of Business and Management 8(22) 32-39. http://dx.doi.org/10.5539/ijbm.v8n22p32

Schmachtel, S., 2015, 'Local partnerships as rationalized myths. A critical examination of the micro-discourse in educational partnership working', Critical Policy Studies, published ahead of print, viewed 8 December 2015 , from $\mathrm{http}: / /$ www.tandfonline. published ahead of print, viewed 8 December 2015, from http://W
com/doi/abs/10.1080/19460171.2015.1077719\#.VmbL2nYrKUk

Sorsa, V., Pälli, P. \& Mikkola, P., 2014, 'Appropriating the words of strategy in performance appraisal interviews', Management Communication Quarterly 28(1) performance appraisal interviews', Management Comm

Spee, A.P. \& Jarzabkowski, P., 2009, 'Strategy tools as boundary objects', Strategic Organization 7(2), 223-232. http://dx.doi.org/10.1177/1476127009102674

Spee, A.P. \& Jarzabkowski, P.A., 2011, 'Strategic planning as communicative process', Organization Studies 32(9), 1217-1245. http://dx.doi.org/10.1177/ 0170840611411387

Statler, M., Jacobs, C.D. \& Roos, J., 2008, 'Performing strategy - Analogical reasoning as strategic practice', Scandinavian Journal of Management 24(2), 133-144. http://dx.doi.org/10.1016/j.scaman.2007.11.00
Strategy-as-Practice International Network., 2016, Bibliography, viewed 6 July 2016, from: http://sap-in.org/bibliography

Stensaker, I. \& Langley, A., 2010, 'Change management choices and change trajectories in a multidivisional firm', British Journal of Management 21(1), 7-27. http:// dx.doi.org/10.1111/j.1467-8551.2009.00657.x

Strutzenberger, A. \& Ambos, T.C., 2014, 'Unravelling the subsidiary initiative process: A multilevel approach', International Journal of Management Reviews 16(3), 314-339. http://dx.doi.org/10.1111/ijmr.12022

Sugarman, B., 2010, 'Organizational learning and reform at New York Police Department', Journal of Applied Behavioral Science 46(2), 157-185. http://dx.doi. org/10.1177/0021886310369088

Sugarman, B., 2014, 'Dynamic capability seen through a Duality-Paradox Lens: A case of radical innovation at Microsoft', in A.B. Shani \& D.A. Noumair (eds.), Research in organisational change \& development, vol. 22(1), pp. 141-189, Emerald Group Publishing Limited. Bringley, United Kingdom.

Suominen, K. \& Mantere, S., 2010, 'Consuming strategy: The art and practice of managers' everyday strategy usage', Advances in Strategic Management 27 211-245. http://dx.doi.org/10.1108/S0742-3322(2010)0000027011

Sztompka, P., 1991, Society in action: The theory of social becoming, Polity Press, Cambridge.

Vaara, E., 2014, 'Struggles over legitimacy in the Eurozone crisis: Discursive legitimation strategies and their ideological underpinnings', Discourse \& Society 25(4), 500-518. http://dx.doi.org/10.1177/0957926514536962

Vaara, E., Junni, P., Sarala, R.M., Ehrnrooth, M. \& Koveshnikov, A., 2014, 'Attributional tendencies in cultural explanations of M\&A performance', Strategic Management Journal 35(9), 1302-1317. http://dx.doi.org/10.1002/smj.2163

Vaara, E., Kleymann, B. \& Seristö, H., 2004, 'Strategies as discursive constructions: The case of airline alliances', Journal of Management Studies 41, 1-35. http://dx.doi. org/10.1111/j.1467-6486.2004.00419.x

Vaara, E. \& Monin, P., 2010, 'A recursive perspective on discursive legitimation and organizational action in mergers and acquisitions', Organization Science 21(1), 3-22. http://dx.doi.org/10.1287/orsc.1080.0394

Vaara, E. \& Pedersen, A.R., 2014, 'Strategy and chronotopes: A Bakhtinian perspective on the construction of strategy narratives', Management 16(5), 593-604.

Vaara, E., Sorsa, V. \& Pälli, P., 2010, 'On the force potential of strategy texts: A critical discourse analysis of a strategic plan and its power effects in a city organization', Organization 17(6), 685-702. http://dx.doi.org/10.1177/1350508410367326

Vaara, E. \& Tienari, J., 2011, 'On the narrative construction of multinational corporations: An antenarrative analysis of legitimation and resistance in a crossborder merger', Organization Science 22(2), 370-390. http://dx.doi.org/10.1287/ orsc.1100.0593

Vaara, E. \& Whittington, R., 2012, 'Strategy-as-practise: Taking social practices seriously', The Academy of Management Annals 6(1), 285-336. http://dx.doi.org/ 10.1080/19416520.2012.672039

Van Wessel, M., Van Buuren, R. \& Van Woerkum, C., 2011, 'Changing planning by changing practice. How water managers innovate through action', International Public Management Journa/14(3), 262-283. http://dx.doi.org/10.1080/10967494. 2011.618305

Vesa, M. \& Franck, H., 2013, 'Bringing strategy to time, studying strategy as experiential vectors', Scandinavian Journal of Management 29(1), 23-34. http://dx.doi.org/ 10.1016/j.scaman.2012.11.005

Voronov, M., 2008, 'Toward a practice perspective on strategic organizational learning', The Learning Organization 15(2), 195-221. http://dx.doi.org/10.1108/ 09696470810852348

Whittington, R., 2002, 'Practice perspective on strategy unifying a developing field', Academy of Management Proceedings 1: C1-C6. http:// dx.doi.org/ 10.5465/ APBPP. 2002.7517994

Whittington, R., 2007, 'Strategy practice and strategy process: Family differences and the sociological eye', Organisation Studies 28(10), 1575-1586. http://dx.doi.org/ 10.1177/0170840607081557

Wright, R., Paroutis, S. \& Blettner, D., 2012, 'How useful are the strategic tools we teach in business schools?', Journal of Management Studies 51(1), 92-125.

Wright State University, 2005, Science news: Great White Shark evolution debate viewed 9 December 2015, from http://www.sciencedaily.com/releases/2005/ 05/050502144430.htm 